\title{
Role of Infrastructure in the Growth of Agriculture in Punjab
}

\author{
Mr. Palwinder Singh, Dr. JasmindeepKaur \\ Research Scholar, Deptt. of Commerce, Punjabi University, Patiala. \\ Associate Professor, Deptt. of Commerce, Punjabi University, Patiala.
}

\begin{abstract}
Punjab is a small state, occupying 1.54 per cent of the geographical area of the country but having a major share in foodgrains production especially wheat and paddy towards the central pool. The growth of agriculture sector has been closely associated with the well known 'Green Revolution' and adoptions of high varieties of seeds and growth in agri-infrastructure in the state of Punjab. Agriculture infrastructure affects the basic economic functions of production, marketing and consumption in a variety of ways. This paper investigates the relationship between institutional agri-infrastructure and volume of agriculture production through coefficient of correlation analysis. The analysis revels that financial institutions have played a dominating role in increasing the volume of agriculture followed by no. of regulated markets and total storage capacity with Govt. agencies during 1990-91 to 2011-12. The study suggested that there is significant need for improving the rural infrastructure for the development of the farming community. The study also recommended that a suitable policy for agri-infrastructure is extremely essential for the agricultural development in the state of Punjab.
\end{abstract}

Keywords: Foodgrain Production, Institutional Infrastructure Growth.

\section{Introduction}

In the state of Punjab wheat and paddy are the most dominating crops accounting for about 80.00 per cent of the gross cropped area. The state has only 1.54 per cent area of the total geographical area of country but contributing about 80.00 per cent toward the central pool of wheat and paddy for last two decades. In the last four decades, the production of wheat in the state has gone up by three times from 5145 thousand tonnes in 1970-71 to 17982 thousand tonnes in 2011-12. During this period, production of rice crop of the state has increased by about sixteen times from 915 thousand tonnes to 15734 thousand tonnes. This growth of agriculture in the state of Punjab has been closely associated with the well know "Green Revolution", adoption of high yield varieties of seeds and growth in agri-infrastructure in the state of Punjab.

Punjab's agriculture has been shifting over the last 50 years but yet it remains a predominantly agrarian economy. According to Punjab Government statistics, Agriculture contributes about 28.00 per cent to the gross domestic product and about 66.00 per cent of population in rural areas is engaged in this profession. The green revolution initiated in mid sixties for wheat and early seventies for rice triggered a high growth trajectory. The rapid growth in wheat and rice contributed substantially to turn the country from severe food deficit to food selfsufficiency in 1975- 76.

The development of the agriculture sector is not only dependent on advancement in technology but also on the improvement of agriculture infrastructure. Adequate infrastructure facilities help in raising production and lowering the unit cost of production activities. Infrastructure both physical and institutional such as rural literacy, irrigation, tube wells, tractors, roads, electricity, regulated markets, storage capacity and financial institutions etc. together play a key role in determining the agriculture output. This paper presents the importance of institutional infrastructure especially for agriculture development. Institutional infrastructure such as regulated markets, storage capacity with Government agencies and financial institutions play a pivotal role in the growth of agriculture sector. Development in the regulated markets can encourage the farmers to increase the amount of sale and take products to the market places instead of selling at the farm gate. Financial institutions play a vital role in development of agriculture sector. Financial institutions provide the credit facilities to buy the equipments such as tractors, pump sets and other durables at low interest rate as compared to private money lenders. This institutional credit further reduces the cost of borrowing and increases the investment in production that enhances the returns to the farmers.

\section{Research methodology}

The study is mainly based on the secondary data. The information has been collected regarding production, regulated markets, storage capacity of procurement agencies and financial institutions (commercial and cooperative banks) from the various issues of Statistical Abstract of Punjab and Economic Survey of 
Punjab. Various statistical tools have been used for the analysis of data such as exponential growth rate, coefficient of correlation and inter-correlation matrix. The study covers the period of 1990-91 to 2011-12.

\section{Results and discussions}

The agriculture output is determined by the number of factors related to institutional infrastructure. Due to the data constraints, five factors have been taken for the analysis.

i. No. of regulated markets in the state of Punjab.

ii. Total storage capacity in Punjab.

iii. No. of Commercial banks in Punjab.

iv. No. of Cooperative banks in Punjab.

v. Output/ production of wheat and paddy which is dependent variables in this analysis.

The exponential growth rate (EGR) of production and market arrival of wheat and paddy crop has been presented in table 1. During the last two decades (1990-91 to 2011-12) production and market arrivals of wheat crop increased in the state and recorded 1.35 and 2.79 per cent exponential growth rate. The results revealed that the exponential growth in production of wheat was 2.58 per cent during 1990-91 to 2000-01. However, during the subsequent decade, the exponential growth in production of wheat decreased and was recorded just 0.24 per cent. Similarly, the exponential growth in market arrival of wheat was more pronounced in 1991-91 to 2000-01 as compared to the subsequent decade.

The result revealed that there was tremendous growth in production and market arrivals of paddy crop during 1990-91 to 2011-12. Data shows that the exponential growth rate in production and market arrivals has recorded 2.38 and 2.82 per cent respectively during 1990-91 to 2000-01. During the subsequent decade, growth rate in production of paddy crop increased which is recorded 2.59 per cent but market arrivals of paddy declined and recorded 2.05 per cent.

Table 1: Exponential growth rate of wheat and paddy production

\begin{tabular}{|c|c|c|c|c|}
\hline Year & & $1990-91$ to $2000-01$ & 2001-02 to 2009-10 & $1990-91$ to $2011-12$ \\
\hline Wheat & Production & 2.58 & 0.24 & 1.35 \\
\hline \multirow{3}{*}{ Paddy } & Market arrivals & 0.63 & -0.21 & 2.79 \\
\hline & Production & 2.38 & 2.59 & 2.60 \\
\hline & Market arrivals & 2.82 & 2.05 & 3.07 \\
\hline
\end{tabular}

In table 2, data indicates that all the indicators related to agriculture infrastructure were positively associated with each other to determine the agriculture production. Data further shows that no. of regulated markets, total storage capacity, no. of commercial banks, and no. of cooperatives banks were positively associated to each other to enhance the agriculture production. Out of the four indicators only no. of commercial banks is significantly correlated with remaining three indicators.

Table 2: Inter Correlation Matrix of Institutional Agri-Infrastructure

\begin{tabular}{ccccc}
\hline & V1 & V2 & V3 & V4 \\
V1 & 1 & 0.263 & $0.913^{* * *}$ & 0.376 \\
V2 & 0.263 & 1 & $0.426^{*}$ & $0.811^{* *}$ \\
V3 & $0.913^{* *}$ & $0.426^{*}$ & 1 & $0.535^{*}$ \\
V4 & 0.376 & $0.811^{* *}$ & $0.535^{*}$ & 1 \\
\hline
\end{tabular}

Correlation is significant at the 0.01 level (2-tailed)

* Correlation is significant at the 0.05 level (2-tailed)

V1: no of regulated markets; V2: total storage capacity with procurement agencies; V3: no. of commercial

banks; V4: no. of cooperative banks in Punjab.

Table 3 shows that all the indicators relating to agriculture infrastructure were individually positively correlated with production of wheat and paddy. Data shows that financial institutions (both commercial banks and cooperatives banks) were strongly correlated with production of wheat and paddy. It was noticed that coefficient of correlation of no. of commercial banks with production of wheat crop was recorded higher $(r=0.84)$ followed by no. cooperatives banks $(\mathrm{r}=0.78)$, regulated markets $(\mathrm{r}=0.76)$ and total storage capacity $(\mathrm{r}=0.58)$. The results reveal that no. of commercial banks and paddy production recorded strong correlation $(r=0.85)$ 
followed by cooperative banks $(r=0.73)$, no. of regulated markets $(0.67)$ and total storage capacity $(r=0.55)$. It has been judged through the value of coefficient of correlation that agriculture infrastructure indicators have positive role to determine the production of wheat and paddy crop.

Table3: Correlation coefficient between agriculture production and the indicators underinstitutional agriculture infrastructure.

\begin{tabular}{|c|c|c|c|}
\hline $\begin{array}{c}\text { Correlation coefficient between } \\
\text { infrastructure and production of wheat } \\
\text { and paddy }\end{array}$ & \multicolumn{3}{|c|}{ Value Of Correlation Coefficient } \\
\hline R01 & & $0762 * *$ & $0666 * *$ \\
\hline R02 & & $0.578 * *$ & $0.548 * *$ \\
\hline R03 & & $0.843^{* *}$ & $0.849 * *$ \\
\hline R04 & & $0.782 * *$ & $0.734 * *$ \\
\hline
\end{tabular}

** Correlation is significant at the 0.01 level (2 tailed)

R01: coefficient of correlation between regulated markets and Production of wheat; R02: coefficient of correlation between storage capacity and production of wheat; R03 coefficient of correlation between number of commercial banks and production of banks; R04 coefficient of correlation between number of cooperative banks and production of wheat

\section{Findings}

From the above discussion it was evident that indicators relating to institutional agri- infrastructure associate to determined the agriculture production in the state of Punjab. This clarifies that institutional agriinfrastructure plays a very supportive role in determining agriculture production in the state of Punjab.

$>$ The manifold increase in the production of wheat and paddy crops might not have been achieved without the successful development of infrastructure in agriculture sector. Over the period of time it has been seen from the results that the exponential growth rate in production and market arrivals of wheat have been recorded 1.35 per cent and 2.79 per cent respectively. During the decade (1990-91 to 200001 ), the production and markets arrivals of wheat increased with 2.58 per cent and 0.68 per cent exponential growth rate respectively and exponential growth rate of production and markets arrivals was stagnant during 2001-02 to 2009-10, recorded exponential growth rate just 0.24 per cent and -0.21 per cent respectively.

$>$ The results revels that there was tremendous growth in production in market arrivals of paddy crop that was recorded at 2.60 per cent and 3.07 per cent exponential growth rate respectively over the period of time.

> All the indicators related to agriculture infrastructure were positively associated with each other. All these indicators were also individually positively associated with production of wheat and paddy. It was noticed that coefficient of correlation of no. of commercial banks with production of wheat and paddy crop recoded strong correlation followed by cooperative banks, regulated market and total storage capacity.

$>$

\section{Conclusions and suggestions}

The study has established strong relationship between institutional agri-infrastructure and volume of agriculture production. The analysis carried relationship between institutional agri-infrastructure indicators and the volume of agriculture production showed that all four infrastructure indicators (no. of regulated markets, total storage capacity with Govt. agencies, no. of commercial banks and no. of cooperative banks) has significantly influenced the volume of agriculture production. Data shows that the impact of institutional agriinfrastructure indicators on the volume of agriculture production appeared to have increased over the time period. Correlation analysis revealed that financial institutions plays a dominating role in increasing the volume of agriculture production followed by no. of regulated markets and total storage capacity with Govt. agencies during 1990-91-2011-12. The study suggested that there is significant need for improving the rural infrastructure for the development of the farming community. The study recommended that a suitable policy for agriinfrastructure is extremely essential for the agricultural development in the state of Punjab. This will support all the sectors of the people in a society and leads to development of agriculture, raise standard of living for the farming communities. The following suggestion will go a long way to bring improvement in this regard:-

$>$ It is required to increase the public investment in these critical areas of agri-infrastructure, especially agriculture depends on it.

$>$ There is a need to further increase the facilities of agri-infrastructure by emphasizing on qualities. 
$>$ In the era of Globalization, the market infrastructure may be of international standards. It can play an important role in improving the quality of farm produce.

$>$ Institutional and structural reforms are needed for promoting the efficiency and viability of agriinfrastructure by infringing excessive bureaucratic control and political interference in the state.

\section{Bibliography}

[1]. Barman, K.R. and Deka, H.C. (1995), "Role of Marketing Institution in Market regulation in Assam", Indian journal of Agriculture Marketing, (conference special), pp.90-96.

[2]. Bhalla, G.S. and Singh G. (1997), "Recent Development in Indian Agriculture: A state Level Analysis", Economic and Political Weekly, Vol. 32, No. 13, PP. 2-18.

[3]. Bhatia, M.S. (1999), "Rural Infrastructure and Growth in Agriculture", Economic and Political Weekly, Vol. 34, No. 52, PP. 43-48.

[4]. Goel, M.M. and WaliaSuraj (2012), “Analysis of agricultural Development in India", The Indian Journal of Economics, Vol 13, No. 370, PP.405- 423 .

[5]. Kumar Sunil (2006), “Agricultutral Marketing Infrastructure and Policy Reforms- An Credit Purveyor's Perspectives”, Indian Journal of Agricultural Marketing, September- December, Vol. 20(3), pp. 1-11.

[6]. PradhanRudraPrakash (2004), "Role of Infrastructure in Agricultural Development: A Study in India", Asian Economic Review, April, Vol. 46, No. 1, pp 83-96.

[7]. Rangi P.S. and Sidhu M.S. (2004), "Development of Market Infrstructure for Globalisation in India", Indian Journal of Agriculture Marketing, (conference special), Vol. 18(3), pp. 1-22.

[8]. Sekhon, M.K. and Rangi P.S. (2007), "Marketing infrastructure for sustainable development- Role of Punjab Mandi Board", Indian Journal of Agriculture Marketing, January- April, Vol. 21, pp. 110-120.

[9]. Sidhu, M.S. and Singh Gaganjot Singh (2010), "A Study on Staggered Public Procurement of Wheat in Punjab", Agricultural Economics Research Review, July-December, vol. 23, pp. 325- 334.

[10]. Singh Balkaran (2000), "Post Harvest Handling and Storage of Agricultural Produce in Punjab", Political Economy Journal of India, January-June, Vol. 9, No. 1, pp 61-62.

[11]. Sukhsanjam, Chahal S.S. and Toor M.S. (2000), “An Impact of Market Regulation on Adequacy of Market Infrastructure in Punjab", Indian Journal of Agriculture Marketing, (conference special), pp. 18-24

[12]. Various issues of Economic Survey of Punjab, Government of Punjab.

[13]. Various issues of Statistical Abstract of Punjab, Government of Punjab. 